\title{
Easterine Kire Iralu's Mari: A Historical Narrative of the Forgotten Battle of Kohima
}

\author{
Veena Gour \\ Research Scholar \\ Barkatullah University \\ Bhopal, M.P, India \\ veena.gour@rediffmail.com
}

\begin{abstract}
Most of the Indians now have forgotten that Kohima was the scene of an Allied victory in the World War II; the victory was so decisive that it changed the contours of the war in Asia. In this significant battle of Kohima, the Japanese force tried to enter India from Naga Hills, advancing progressively into Asia after the success of their Burma campaign in 1941-42. But in Kohima they were defeated convincingly by the British Allied Forces which were helped by local inhabitants in the battle. The Japanese had broken down equally by disease and hunger thus left their plan to enter in India. The Battle of Kohima often refers by Nagas as a 'forgotten battle' and its heroes as the 'forgotten heroes'. Easterine Kire Iralu's Mari stands as a distinct novel as it commemorates the forgotten Battle of Kohima of 1944. The novel is a fascinating love story set in the midst of this war. It is an enchanting tale of Iralu's aunt
\end{abstract}


Khrielievu Mari O' Leary who was engaged to a British sergeant Victor. The novel is written in form of a diary which Mari maintained during the war meticulously registering every event of her life. Mari is not just a story of a young girl falling in love but it's a story of all those people who lived that war- time. This paper examines the impact of the battle of Kohima on the culture, identity and traditional values of Naga society which the writer has described in the backdrop of Mari's life journey in the novel.

Keywords: Battle of Kohima, Naga society, culture, identity, traditional values

History is an outcome of real socio-cultural experiences of people in a given society at a given point of time. It provides an intimate knowledge of the people and land. Easterine Kire Iralu's Mari (2010) records the true experience of Naga people as it is based on the forgotten Battle of Kohima, when the Japanese force invaded India under the British rule in 1944. Most of the Indians now have forgotten this significant battle in which Japanese force tried to enter India from Naga Hills during the World War II, advancing progressively into Asia after the success of their Burma campaign in 1941-42. Kohima witnessed the horror of this Battle between British Allied forces and Japanese forces. The "Battle of Kohima", as it is called now, was a gory affair. It was so decisive that it altered the contours of the World War II in Asia. The Japanese were defeated convincingly in the battle on the Naga Hills by the British troops who were immensely supported by local Naga inhabitants. The Japanese also lost their initiative to enter in India as many of their soldiers died due to disease and hunger on their way in the impenetrable terrains between Burma and Kohima. The present-day Kohima was the site of the Battle. The town of Kohima, in 1944, was a sleepy British outpost, consisting of mostly government offices and residences. The battle lasted for three months, from April to June 1944, and left over 10,000 dead on both sides. The battle is a noteworthy event in the history of Naga society and compared to the 'big bang' by Nagas. 
Kire has credibly documented and restored the real history of the war that needs to be revisited for the understanding of the Nagas. The novel offers a resourceful reading to nonNaga audience who wishes to have an insight into the Naga society.

Mari is an enthralling diary novel set in a familiar tradition of novels and films describing a love story in a turbulent backdrop of World War II. It is a literary souvenir of the once little peaceful town that became the grave of the Japanese imperial dreams. The protagonist here is Mari, short for Khrielieviu Mari O'Leary, the 17-year-old daughter of a Treasury officer in the District Commissioner's office in Kohima, who falls in love with a 30years old Staff Sergeant Victor (Vic), a British soldier. The novel is a semi-fictional autobiography of Mari, written in first person. It is based on the stories which she narrated to Kire, her niece, about the crucial years of her youth and the diary she maintained during the war years meticulously registering every event of her life. The novel for the first time presented the insiders perspective on the war and the way it affected the Nagas. The novel is not just documenting the story of Kire's aunt, but it also mirrors the community experience of all those people who lived that war time. And it also explores various aspects of culture, identity and traditional values of Naga society which the writer has described in the backdrop of Mari's life journey in the novel. In this novel, Kire also acknowledges the oral narrators of her society who transferred their socio-cultural beliefs and values from one generation to another through their exciting stories of the past, and also kept alive the memories of life changing events like World War II and the Japanese invasion of Nagaland. Easterine Kire writes, "For Mari and other of her generation, World War II and the Japanese invasion of our lands was the most momentous period of our lives....All my oral narrators told me this about the war: 'It altered our lives completely.' What is so remarkable about the World War II, which is still referred as The War by the Nagas, is that the people have very little memory of 
what they were doing before the war years. I was left with the impression that the war is equivalent to the big bang, the beginning of all life." (Introduction viii)

The novel Mari naively and delicately captures the life story of an innocent, carefree and oblivious seventeen years old girl Aviu (loving called Mari by her fiancé). It is a sensitive recounting of her falling in love with British soldier Victor- their meeting, the pursuit, their courtship and consummation amidst the horror of war that engulfed their serene town Kohima. Kire through her skilled prose created idyllic pre-war setting of the town, Kohima, where, Mari lived with her family of seven members in a two storey house called Bamboo Villa, in a colony known as Mission Compound in the outskirts of Kohima Village. The picturesque beauty of the house was mounted by its terraced herb patches, orchard, vegetable garden, flower beds and a little stream flows beyond the bamboo grove at the entrance. The town itself was vibrant and colorful with it all round the year blooming daisies, rhododendrons, pink bohemia and the scarlet flame of forest. Life portrayed before the war unfolds the entire lost era of rhythmic peaceful life people of Kohima. "In these pre-war years, there was a steady rhythm to our lives in our little town. Every morning we see the same sight." (Mari, 14)

In 1942, a change brought to the peaceful pastoral life of Kohima when the shadow of war started looming over it. The novel depicts how Kohima underwent rapid transformation with the building up of modern infrastructure like new roads and buildings. War preparation became more apparent. Initially, the countless rumors spread about the Great War via radio. The news of bombing Pearl Harbour before Christmas in 1941 sounded to people like a faraway event that cannot affect them in the remotest corner of the world. But then, soon it came close to their home when fighter planes frequently started flying overhead creating immense excitement initially in villagers who ran out to have glance of them. Soon the peaceful town turned into an army cantonment and roads filled with grey smoke due to the 
frequently moving British convoys and army vehicles. Gradually the war turned its uglier face when hordes of "starving, diseased" refugees start coming in from the Burma border.

Kire portrayed a picture of the simple, easy-going life of the Nagas in the green, verdant countryside befriending and enjoying with the camping soldiers before everything had really engulfed in the life-changing war. Along with amusing holidays, gathering herbs and picnics in the field, Kire skillfully produces the sense of impending tragedy of war. Mari is an engrossing romantic novel. As Easterine Kire asserts, "In retrospect, there are many who continue to see the war years as the best years of their lives. It has been that romanticized. Grim? Certainly. But they were years filled with all elements of romance: heroic deeds, the loss of lives, fear, uncertainty and deep love. These are all parts of Mari's story." (Introduction, ix)

The two plot moves simultaneously in the novel, the growing love between Mari and Vic, as well as the preparations of the war which upturned everybody's life. The plot swiftly moves when Mari tries to overcome her inhibition towards mature Vic; thus gradually from mere infatuation their relation turns into a lifelong bond. The family accepted their relationship and with the blessings of the family they were engaged. Ironically, along with the growing hope to live happily for each other after the war got over, the war too approached closer to Kohima bringing fear and sense of uncertainty for life itself. It suddenly came, upturned and destroyed everything. The entire family got separated- being Treasury Officer Mari's father had to go to Shillong, her both younger sisters were sent to nearby village Chieswema. In the unusual time of war, the conventional code of morality became irrelevant and Vic moved to Mari's house well accepted as her husband without any ceremonial wedding. But, soon they too were parted due to the Japanese siege on Kohima. Mari was also sent to Chieswema to take care of her younger sisters and Vic had to move to his post on Garrison Hill. 
"The battle for Kohima can be divided into two phases: the siege, which lasted for 13 days; and the clearance of Japanese $31^{\text {st }}$ Division from the area, followed by the opening of Kohima-Imphal road, from mid-April until 22 June. This second stage occurred over the course of two months and caused more casualties for both." ${ }^{1}$ There was a siege on Kohima for about two weeks from $4^{\text {th }}$ April 1944 which was lifted on $19^{\text {th }}$ April 1944 . The fierce fighting took place during this time. The entire town was destroyed and ablaze in shelling from either side. Though, the war continued for another two months, to force out Japanese forces from northern Angami villages and to the east of Kohima. But, before the siege was lifted, Vic died by a sniper's bullet on $18^{\text {th }}$ April.

Though the novel romanticized the war -"the Japanese invasion of Nagaland", but the protagonist Mari is not a war hero rather she was the survivor. Many tribes in Nagaland were actively involved in fighting, siding British allied forces as guide, scouts, carrying goods and messages for them as well as spying over Japanese forces. But, Mari took no part in this. She along with her sisters and various other local inhabitants of Naga Hills was forced to seek out shelter in forest, running over hills and valleys in order to hide from advancing Japanese forces. It was a hard time, shelling on villages along with unending firing of bullets were going on and food was such a shortage that even forests run out of herbs. During this perilous time, Mari discovered her pregnancy. But before sharing this joy with anyone, she found out in May that Vic has been killed in the war. Her world collapse, she was just eighteen- a widow and expecting a child. Though sorrow stricken and brooding over her lost husband's memory she choose to pick the scattered pieces and tries to start her life again.

The rest of the novel describes Mari's life and her efforts to reconstruct it to make for the loss she suffered due to the war. She candidly narrated her relationship with another British soldier, Dickie, and tried to find love again after Vic's death. She even had a daughter, by him. Mari very honestly recounted her wrongly made decision as this romance leads 
nowhere and narrated the unbearable pain of parting from those who did not mean to be a part of her life. Dickie was transferred back to Britain and Mari unwilling to leave her family in Kohima, choose to stay back. In order to support her small family of two daughters, she decided to fulfill her dream which she perceived before the war time, to become a nurse. Thus, eventually went to Ludhiana and then Delhi to study further and trained as a nurse and ultimately finds a job in Digboi Assam Oil Company Hospital. Here she met Patrick O’Leary (Pat), a tea planter, falls in love and married him. And finally in this marriage she finds peace and security which was denied to her in earlier relationships.

Kire swiftly moves in the last part of the novel pausing only to register the important events of Mari's life, such as the deaths of her parents, the marriages of her daughter, Pat's illness and death. It was as if, for Mari, the war and the ravages of it were the only enduring memories - the rest was merely a post-script. Kire through the life's journey of the protagonist Mari explored the hidden past of Naga people, their native culture and traditions which established their distinct identity. "In using real history to explain her perspective, Kire has credibly restored documents that are viable for understanding of the Nagas. It offers a resourceful reading to non-Naga audience who wishes to have an insight into the Naga society."2

Through the love story of the protagonist, Kire gracefully presented the cultural and historical past of Nagaland. Being Angami herself, Kire glorified the native identity of Angami people, their culture, traditions, values as well as the lost beauty of the region in her simple style which suites to the subject. Mari's story is the story of all those women, who lost their husbands as well as near and dear ones in this battle, remained unrepresented, voiceless and marginalized so far. But these women quietly and courageously took control over their destinies by believing in themselves. Kire tries to portray problems of not just women but all people of Nagaland whose stories throughout these years remained unsaid and hidden from 
rest of the world. She presented the insider's perspective of problems faced by Naga people at the same time saved the cultural values of her society from misinterpretation. The novel is also an attempt to show gratitude for all those people who selflessly sacrifice their life for the motherland in the World War II but now forgotten by the present generation. Though the writer devotes much of her attention on Mari's life but simultaneously it also depicts the changes which came to the region after the war due to modernization, globalization as well as growing influence of Christianity over the traditional beliefs.

Easterine tried her best to bring out the plight of Naga people when displaced from their lands during battle of Kohima. Before the war, Nagas accepted British colonial rule over them. They suffered a lot at the hands of both British and Japanese forces but their sufferings were sidelined and suppressed in all the documentary evidences of the war. The pain of being displaced from their own land created a new sense of identity and ownership among them. Later it paved the way for Naga freedom struggle from the Indian Union after the British colonial rule ends in India. The resilient spirits of Nagas was also highlighted in text during the period of reconstruction after the war. Leaving behind the dreadful memories of the war, they tried to reconstruct the town as well as the life as beautifully as possible. The support which they provided to British-Allied forces in winning the battle against the Japanese and their sacrifices to the mother land always fills the coming generation with pride. The writer tried to narrate these lost stories of their undaunted heroism to the outside world.

It is evident that postcolonial historians focused only on the history and culture of the dominant one and the reframe the history of the oppressed class according to their own benefits. Thus most of the time, the facts and real history remain hidden from the mass. The Naga voices were marginalized likewise. "Easterine attempts to bring the marginalized to the centre and endow them with the fair amount of respect from which they were debarred. By bringing them to the focus, Kire rewrites the history of subaltern in the postcolonial 
historiography."3 Mari thus brings back forgotten voices of Nagas which were cornered by both the alien forces and shows indispensible role of Nagas in the Battle of Kohima. The arrival of British on their land had broken their isolation from rest of the world. The strategic location of Nagaland made it significant for British and helps them to govern the other adjacent areas of commercial importance. The writings of the period only recorded the British attempts to merge the Naga Hills inhibited by savage and uncivilized tribal. Kire's writings tries to clear this negative image attributed to Nagas by the westerners. Being a Naga herself she feels responsible to depict intricate issue of their culture and tradition thereby presents the image of real Naga life. This novel presents the oppressed and marginalized Nagas which were always portrayed as powerless and uncivilized by the historians. Later, the turmoil of the region concealed the true Naga culture and identity. Easterine took a bold step to redefine the history from native's point of view. As Mari asserted in the end of the novel that it seems the past and the present are intermingling now. The past is valuable to the present generation as it enlightens them about the glory of sacrifices made by their ancestors for post war generations.

The paradigm shift ushered in by the WWII in Kohima undoubtedly created new cultural icons in the Naga lives thereafter. The Kohima War Cemetery is one example of it. The inscription on the war memorial of the 2nd Division at the Kohima War Cemetery says, "When you go home tell them of us and say for your tomorrow we gave our today." The words have become a parameter of the depth of attachment and involvement of the Naga Hills during the war.

This is basically what the story deals in. The novel commemorates the war times and in this process, the journey of the protagonist's life through all the upheavals, reveal the strength of her character and resilience in her spirit. Mari's journey realizes what it takes to be a woman and a single parent. Mari becomes the role model that everyone looks up to as 
SMART MOVES JOURNAL IJELLH e-ISSN: 2582-3574 p-ISSN: 2582-4406 VOL. 8, ISSUE 11, NOVEMBER 2020

she continues to enthrall all who pause to listen to her story. Her identity is established through the story. She 'becomes'. 


\section{Works Cited}

Battle of Kohima, North East India File www.gov.uk.: Pg.3 Accessed on 20 May 2019.

Patton, W. Meribeni “The Fictional Narrative of Easterine Kire: A New Historicist Study”, Ars Artium, ISSN: 2395-2423 Vol-6 Jan 2018: Pg. 31-32.

Choudhary, Sukannya “The Voice of the Voiceless: An Analytical Study of Easterine Kire's Mari”www.academia.edu.in accessed on 15 December 2018.

Kire, Easterine. Mari. HarperCollins Publishers, New Delhi, 2010. 